\title{
Pohjoismaista tutkimusyhteistyötä kasvatuksen ja koulutuksen sukupuolikysymyksistä
}

\author{
Pohjoismaisessa koulutustutkimuksen verkoston NERA:n, \\ yhteydessä toimii myös sukupuoleen ja koulutukseen keskittyvä \\ verkosto, Gender and Education network. Millaisia asioita nousi \\ esille, kun tutkijat tapasivat Jyväskylässä viime keväänä?
}

POHJOISMAISTA USEITA TUTKIJOITA kokoontui maaliskuussa Jyväskylässä järjestettyyn pohjoismaiseen kasvatustutkimuksen NERA-konferenssiin (Nordic Educational Research Association, www.nfpf. net) keskustelemaan sukupuolesta kouluissa ja opettajankoulutuksessa. NERA-järjestön organisoimassa jokavuotisessa konferenssissa on kauan toiminut sukupuoleen ja koulutukseen keskittynyt verkosto (Gender and Education network), joka tavallisesti järjestää konferenssiin työryhmäsessioita. Niissä on pidetty esitelmiä myös sukupuolinäkökulmaisesta aikuiskasvatustutkimuksesta.

Tänä vuonna Jyväskylässä verkosto järjesti yhteistyössä opetusministeriön rahoittaman maaliskuussa päättyneen "Tasa-arvo- ja sukupuolitietoisuus opettajankoulutuksessa" -projektin (TASUKO, 2008-2011, ks. http://wiki.helsinki.fi/display/ tasuko) kanssa esikonferenssin, jossa paneuduttiin erityisesti opettajankoulutukseen ja siihen liittyvään tutkimukseen. Pohjoismaiden ministerineuvosto rahoitti esikonferenssin järjestämistä (ks. tarkemmin www.minna.fi/web/guest/opettajankoulutuskonfe- renssi). Verkosto osallistui myös kutsuttuna tahona Amerikan kasvatustutkimuksen järjestön (American Educational Research Association, www.aera.net) konferenssiin huhtikuussa New Orleansissa, jossa se järjesti pohjoismaisen tutkimussymposiumin (www.nfpf.net/?p=791).

NERA:n Gender and Education -verkosto on keskeisin yhteispohjoismainen kanava alueen sukupuolitutkimusta kasvatuksen ja koulutuksen kysymyksistä tekeville. Pohjoismaisella aihepiirin tutkimusyhteistyöllä on pitkät perinteet ja usein yhteistyötä on tehty erityisten projektien puitteissa. Esimerkiksi ammatilliseen koulutukseen keskittyvä Avaa/Brythanke 1980-luvulla ja opettajankoulutuksen tasa-arvoa edistävä NordLilia-hanke 1990-luvulla kokosivat yhteen alan tutkijoita Pohjoismaiden ministerineuvoston rahoituksen turvin.

2000-luvulla etenkin koulutuksen sukupuolittunutta ja seksualisoitunutta väkivaltaa analysoivat projektit ovat löytäneet yhteistyötahoja lähialueen maista. Näitä Oulun yliopistossa Vappu Sunnarin johdolla organisoituja väkivaltateemaisia projekteja 
ovat rahoittaneet usein Euroopan unionin rahastot ja ohjelmat. Helsingin yliopistossa Elina Lahelman vetämällä "Kansalaisuus, toimijuus ja erot toisen asteen koulutuksessa - painopisteenä ammatilliset oppilaitokset" -hankkeella (Suomen Akatemia 2010-2013) on tiiviit pohjoismaiset suhteet ja sen NordCritverkoston norjalaiset, ruotsalaiset ja suomalaiset tutkijat sisällyttävät tutkimuksiinsa yleensä sukupuolinäkökulman.

Pohjoismainen yhteistyö jatkuu Gender and Education- verkoston tukemana. Sukupuoleen, seksuaalisuuteen ja niihin liittyviin muihin eroihin keskittyvillä aikuiskasvatuksen tutkijoillakin on mahdollisuus osallistua NERA:n sukupuoliteemaisen verkoston järjestämiin työryhmäsessioihin. Seuraava konferenssi on Kööpenhaminassa 8.-10.3.2012. Lisäksi aihealueen tutkijat ovat tervetulleita vastaikään perustetulle verkoston sähköpostitiedotuslistalle ilmoittautumalla verkoston vetäjälle (jukka.p.lehtonen@ helsinki.fi).

\section{POHJOISMAINEN KOULUTUKSEN JA SUKUPUOLEN TUTKIMUS}

Tasa-arvo- ja sukupuolitietoisuus opettajankoulutuksessa -hankkeen yhteydessä tein yleiskatsauksen suomalaisesta opettajankoulutustutkimuksesta ja siitä, millainen sukupuolen asema siinä on (Lehtonen 2011). Samassa yhteydessä tarkastelin hieman suomalaista tutkimuskenttää suhteessa pohjoismaiden tilanteeseen.

Hyödynsin tässä yhteydessä pohjoismaisia kartoituksia vuosien 1990-2005 ja vuosien 2005-2009 välillä julkaistuista sukupuoli- ja kouluteemaisista teksteistä ja ruotsalaista sukupuolinäkökulmaista koulututkimuksen meta-analyysia ja siihen liittyvää bibliografiaa vuosien 1969-2005 kouluaiheista tutkimuskirjallisuudesta (Bibligrafiutkast 2005; Bodenstam 2010; Carlberg \& Bondestam 2010; Nyström 2009, ks. myös Wernesson \& Ve 1997; Eurydice 2010; Lynch \& Feeley 2009). Pohjoismaisissa kartoituksissa ilmenee, että Ruotsissa aihepiirin tutkimusta on enemmän kuin muissa Pohjoismaissa. Suomessa ja Norjassa puolestaan näyttää olevan sitä enemmän kuin Tanskassa ja Islannissa (Bibliografiutkast 2005; Nyström 2009, 13, 21).
Kaikissa maissa on muutama tutkija, joka on julkaissut aiheesta runsaasti. Suuri enemmistö tutkijoista oli naisia. Ruotsalaisen tutkimuksen mukaan naispuoliset opettajakouluttajat ovat mieskollegojaan kiinnostuneempia paitsi sukupuolen tasa-arvon edistämisestä myös tutkimuksesta yleisesti (Erixon Arreman \& Weiner 2007). Tanskassa suuri osa julkaisuista painottuu 1990-luvulle, kun muissa maissa julkaisuja on melko tasaisesti sekä 1990-luvulta että 2000-luvulta. Melko pieni osuus kaikesta esitellystä tutkimuskirjallisuudesta näytti paikantuvan erityisesti opettajankoulutuksen ja pedagogisten ratkaisujen analyysiin. Tekemässäni analyysissa Suomen tilanteesta vastaava suuntaus sai vahvistusta (Lehtonen 2011). Pääosa alan suomalaisista tutkimuksista on tehty 1980-luvun jälkeen.

Suomen ja Islannin tutkimuksen sisällöllinen arviointi oli hankalampaa toteuttaa kielisyiden takia kuin muiden maiden, joten sen esittely jäi epämääräisemmäksi pohjoismaisessa kartoituksessa ( $\mathrm{Ny}$ ström 2009). Eva Nyströmin (2009) selvityksen mukaan sukupuolen käsittämisen tavat ovat muuttuneet vuosien aikana ja 2000-luvulla erityisesti intersektionaalisuus, sukupuolen tarkastelu muiden erontekojen kuten yhteiskuntaluokan, etnisyyden ja seksuaalisuuden, rinnalla on yleistynyt samoin kuin heteronormatiivisuuden analyysi.

Meta-analyysissa ruotsalaisesta sukupuolinäkökulmaisesta koulutuksesta todettiin, että vuosien 1969-2009 välillä julkaistuja tutkimusjulkaisuja löytyi 1438 (Carlberg \& Bodestam 2010). Tutkimuksia alkoi ilmestyä selvästi useammin 1990-luvun alkupuolen jälkeen ja niiden määrä on ollut 2000-luvulla hienoisessa laskusuunnassa. Tutkimuksista suurin osa käsitteli peruskouluun ja erityisesti luokkahuoneeseen liittyviä teemoja ja vain kuusi prosenttia niistä käsitteli opettajankoulutusta. Niistä enemmistö oli opinnäytetöitä. Suurin osa käsitteli tyttöjä ja poikia, tavallisesti keskittyen etsimään näiden ryhmien välisiä eroja. Varhaisemmat julkaisut käsittelivät useammin tyttöjä. 1980-luvulla käsiteltiin sekä tyttöjä että poikia, mutta tyttöjä selvästi useammin. 1990-luvulla poikiin kohdistuva tutkimus lisääntyi yhtä suosituksi tyttöaiheisen kanssa ja 2000-luvulla pojista tehtiin enemmän tutkimuksia kuin tytöistä. 
Huoli pojista - ja miehiä tarvitaan opettajiksi -tyyppinen tutkimusasetelma on ollut suosittua myös ruotsalaisessa tutkimuskentässä, vaikkakaan ei niin suosittua kuin Suomessa ja Norjassa (Arnesen ym. 2008; ks. myös Lahelma ym. 2000). Käsitteistä sukupuolirooli ja -ero sekä feminismi olivat tyypillisempiä 1970-luvun julkaisuissa kuin myöhemmin. Tasa-arvo ja sukupuoli (ruotsinkielessä usein genus) ovat olleet suosittuja kautta aikajakson, mutta niiden merkitys on vähentynyt 2000-luvulla. 1990-luvun lähtien uusia, suosiota saaneita käsitteitä ovat olleet heteronormatiivisuus, intersektionaalisuus, queer ja maskuliinisuus. (Bondestam 2010.) Kehitys on samansuuntaisena Suomessa, vaikka pienemmän tutkimusmäärän takia vastaavia erotteluja käsitesuuntauksista on hankalampi tehdä.

Meta-analyysin perusteella Fredrik Bondestam (2010, 101-102) ehdottaa opettajankoulutusta kehitettäväksi niin, että siihen integroidaan sukupuolinäkökulma systemaattisesti. Hän arvioi opettajankoulutusta koskevan julkaisukokonaisuuden paitsi vähäiseksi myös laadultaan - sekä menetelmällisesti että teoreettisesti - melko puutteelliseksi. Keinona parantaa opettajien osaamista ja samalla myös tutkimusaluetta on hänen mukaansa se, että opettajista koulutetaan toimintatutkimusta osaavia opettajia, joille on annettu valmiudet teoreettisesti ja menetelmällisesti sekä asiasisällöllisesti analysoida sukupuolta. Sama lähtökohta voisi aktivoida myös Suomessa opettajakoulutettavia analysoimaan sukupuolta koulutuksessaan ja opettajan työssään.

\section{AIKUISKASVATUS MARGINAALISSA?}

Entä sukupuolinäkökulmaisen aikuiskasvatuksen asema pohjoismaisessa tutkimuskentässä yleisemmin? Opettajankoulutustutkimukseen keskittyvässä analyysissani en erikseen analysoinut aikuiskasvatustutkimusta, mutta tutkimus painottui pääasiassa muualle kuin aikuiskasvatukseen ja etenkin se keskittyi peruskouluun. Aikuiskasvatuksen kentälle sijoittuva opettajankoulutuksen tutkimus sai Suomessa uutta puhtia TASUKO-hankkeesta, jonka puitteissa tehtiin kiinnostavia tutkimuksia opettajaopiskelijoiden ja -kouluttajien näkemyksistä sukupuolitietoisuudesta (ks. esim. Jauhianen ym. 2011; Vidén \& Naskali 2010; Syrjäläinen \& Kujala 2010).

Aikuiskasvatuksen sukupuolinäkökulmaa on kaivattu ja toisaalta aikuiskasvatusnäkökulmaa on edellytetty sukupuoli ja koulutus -teemaiselta tutkimusyhteistyöltä (ks. Aikuiskasvatus 4/2001; Vuorikoski 2003: Vuorikoski \& Ojala 2006). Turun yliopiston Annukka Jauhiaisen ja Anne Laihon mukaan koulutuksen tasa-arvokysymykset ja alan tutkimus painottuvat usein yleissivistävään koulutukseen, vaikka sukupuoliteemat ja niiden tutkimustarve koskettavat yhtä lailla myös ammatillista koulutusta ja aikuiskasvatusta sekä korkeakoulutusta (Hakala ym. 2011; ks. myös Brunila 2010).

Yksi mahdollisuus keskustella sukupuolinäkökulmaisesta aikuiskasvatustutkimuksesta pohjoismaisesta näkökulmasta tarjoutuu NERA:n Gender and Education -verkoston puitteissa. Esimerkiksi esitys aikuiskasvatukseen ja sukupuoleen keskittyvästä tutkimussymposiumista seuraavaan NERA-konferenssiin on tervetullut.

Jukka Lehtonen on seksuaali- ja sukupuolivähemmistöjen tutkija, jota kiinnostavia ongelmia ovat heteronormatiivisuus koulussa nuorten kokemana (väitöstutkimus 2003) sekä seksuaalisten vähemmistöjen ongelmat työelämässä ja koulutuksessa. Hänet palkittiin vuonna 2006 näistä ansioista Helsingin yliopiston myöntämällä Maikki Friberg-tasa-arvopalkinnolla.

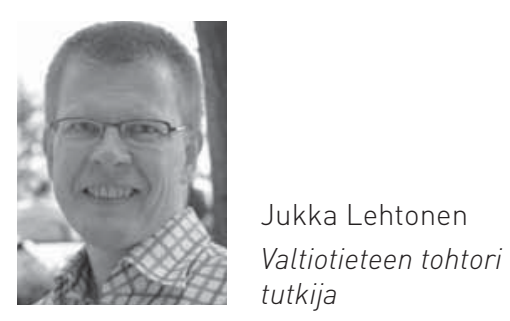




\section{KIRJALLISUUS}

Aikuiskasvatus 2001 Aikuiskasvatus ja sukupuoli teemanumero. Aikuiskasvatus, 20 (4).

Arnesen, A-L., Lahelma, E. \& Öhrn, E. 2008. Travelling discourses on gender and education. The case of boys' underachievement. Nordisk Pedagogik, 28 (1), 1-14.

Bibliografiutkast (2005). Forskning med fokus på skola, kön \& jämställdhet/likestilling i Norden, publicerad 1990-2005. Oslo: NIKK (www.nikk.no)

Bondestam, F. (2010). Kunskap som befrielse? En metaanalys av svensk forskning om jämställdhet och skola 1969-2009. Rapport II. SOU 2010:35. Stockholm: Delegationen för jämställdhet i skolan.

Brunila, K. (2010). Sukupuolten tasa-arvo korkeakoulutuksessa ja tutkimuksessa. Selvityksiä 2009:51. Helsinki: Sosiaali- ja terveysministeriö.

Carlberg, M. \& Bondestam, F. (2010). Svensk forskning om jämställdhet och sola 1969-2009. En bibliografi. Rapport IV. SOU 2010: 36. Stockholm: Delegationen för jämställdhet i skolan.

Eurydice (2010). Gender Differences in Educational Outcomes: Study on the Measures Taken and the Current Situation In Europe. Brussels: European Commission. (http://eacea.ec.europa.eu/education/ eurydice/documents/thematic_reports/120EN.pdf)

Hakala, K. , Jauhiainen, A., Kurki, T., Lahelma, E., Laiho, A., Lappalainen, S., Mietola, R., Niemi, A-M., Palmu, T. \& Lehtonen, J. (2011). Eroja ja siirtymiä jäljittämässä. Tutkimuksia peruskoulun jälkeisistä koulutuksista. Teoksessa Lehtonen, Jukka (toim.) Sukupuolinäkökulmia tutkimusperustaiseen opettajankoulutukseen. Tasa-arvo- ja sukupuolitietoisuus opettajankoulutuksessa -projektin julkaisu. Helsinki: Helsingin yliopisto, 129-145.

Jauhiainen, A., Kovalainen, P. \& Laiho, A. Itulossa 2011) Opiskelijanäkökulma tasa-arvo- ja sukupuolitietoisuuden huomioimiseen Turun yliopiston kasvatustieteiden tiedekunnassa. Turun yliopiston Kasvatustieteiden laitos. Turku: Turun yliopisto.

Lahelma, E., Hakala, K., Hynninen, P. \& Lappalainen, S. (2000). Too few men? Analysing the discussion on the need for more male teachers. Nordisk Pedagogik, 20 (3), 129-138.

Lehtonen, J. (2011). Sukupuoli opettajankoulutukseen liittyvässä tutkimuksessa. Teoksessa Lehtonen, Jukka (toim.) Sukupuolinäkökulmia tutkimusperustaiseen opettajankoulutukseen. Tasa-arvo- ja sukupuolitietoisuus opettajankoulutuksessa -projektin julkaisu. Helsinki: Helsingin yliopisto,178-238.
Lynch, K. \& Feeley, M. (2009). Gender and Education. Brussels: European Commission. (http://www. nesse.fr/nesse/activities/reports/gender-report-pdf)

Syrjäläinen, E. \& Kujala, T. (2010). Sukupuolitietoinen tasa-arvokasvatus - vaiettu aihe opettajankoulutuksessa ja koulun arjessa. Teoksessa Suortamo, Markku, Tainio, Liisa, Ikävalko, Elina, Palmu, Tarja \& Tani, Sirpa (toim.) Sukupuoli ja tasa-arvo koulussa. Jyväskylä: PSkustannus, 25-40.

Vidén, S. \& Naskali, P. (2010). Sukupuolitietoisuus Lapin yliopiston opettajankoulutuksessa. Lapin yliopiston kasvatustieteellisiä julkaisuja 22. Rovaniemi: Lapin yliopisto

Vuorikoski, M. (2003). Opettajien yhteiskunnallinen valta ja vastuu. Teoksessa Vuorikoski, Marjo, Törmä, Sirpa \& Viskari, Sinikka (toim.) Opettajien vaiettu valta. Tampere: Vastapaino, 17-53.

Vuorikoski, M. \& Ojala, H. (2006). Sukupuoli aikuiskasvatuksen kohteeksi. Aikuiskasvatus, 26 (4), 316-322.

Wernesson, I. \& Ve, H. (1997). Research on gender and education in the Nordic countries. Scandinavian Journal of Educational Research, 41 (4), 295-317. 